\title{
Dmytro Shtohryn (1923-2019)
}

Dmytro Shtohryn, long-time Slavic librarian and member of the University of Illinois at Urbana-Champaign (UIUC) faculty, died on September 25, 2019. Dmytro's extraordinary contributions to Slavic, east European, and Eurasian studies, particularly to Ukrainian studies, will remain a source of inspiration for generations of scholars.

Dmytro Shtohryn's long and eventful life mirrored the vicissitudes of the twentieth-century's tumultuous history. A son of Mykhailo and Kateryna Shtohryn, he was born on November 9, 1923, in Zvyniach, Ternopil region, Ukraine. Along with many other Ukrainians, he was displaced during World War II to Germany. While living in a displaced persons camp in Augsburg, he attended the Ukrainian Free University in Munich. Professor Shtohryn continued his education at the University of Minnesota after his immigration to the United States in 1948. During that time he also volunteered as a leader of a Ukrainian scout unit. He met his future wife, Eustachia (née Barwinsky), also a scout leader, on a trip to Winnipeg with his unit. The two married in 1955 and shared sixty-four years of marital happiness.

Dmytro Shtohryn continued his education at the University of Ottawa, Canada, where he earned a Bachelor degree in Library Science, as well as a MA and PhD in Slavic Studies. The subject of his dissertation was a prominent member of Ukraine's “executed Renaissance," the poet and literary critic Pavlo Fylypovych. In 1960, Professor Shtohryn joined the UIUC library and became one of the founders of its world-renowned collection. The University Library is now home to the third-largest Slavic, east European, and Eurasian collection in the country, with over 650,000 print volumes in regional languages, well over 100,000 archival microforms, and 6,000 periodicals, primarily in vernacular languages. Under Dmytro's curatorship (1960-1995), the Ukrainian studies collection became one of the largest in North America.

In honoring his contributions, Dr. Volodymyr Serhijchuk (Taras Shevchenko National University of Kyiv) connects Dmytro's work to sustaining the Ukrainian idea abroad of a joyous return to a free Ukraine. Dmytro's friends and colleagues alike witnessed his life-long dedication to the preservation of Ukrainian culture. One his initiatives, among many, was the establishment of annual conferences on Ukrainian studies at the University of Illinois, which became a true oasis for Ukrainian scholars from around the world. The inaugural conference took place June 24-28, 1982. Working closely with colleagues from home and abroad, Dmytro presided over twenty-five international conferences over the years. These conferences created a lasting outlet for intellectual inquiry in the area of Ukrainian studies.

In addition to his library appointment, Dmytro was closely affiliated with the UIUC Department of Slavic Languages and Literatures and continued to teach Ukrainian language, literature, and culture and to support the 
Ukrainian annual conference long after his retirement in 1995. He was also a visiting professor of the University of Ottawa, the Catholic University in Rome, and the Ukrainian Free University in Munich. He was an active member of many professional and scholarly organizations in our field, including the Association for Slavic, East European, and Eurasian Studies and the American Library Association (chairman of its Slavic and East European Section), and served on executive committees of the Shevchenko Scientific Society in America, the Ukrainian Academy of Arts and Sciences in the US, and the Ukrainian Historical Association. He was co-founder and longtime president of the Ukrainian Library Association of America and the Ukrainian Academic and Professional Society.

Over the course of his long and productive life, Dmytro presented his work at numerous scholarly conferences in the United States, Canada, Germany, and Ukraine and authored or edited six books and about 100 articles in English, Ukrainian, and German. In his honor and through the generosity of his daughter, Liuda Shtohryn, the Dmytro Shtohryn Endowment in Ukrainian Studies was established at the University two years ago.

While Dmytro tirelessly promoted the study and preservation of Ukrainian national culture, he was also open to the concept of Ukraine as a multiethnic and multicultural state. The last event in the Slavic Department that he attended was the November 2018 workshop on Kyiv Kultur-Lige, which explored parallel Jewish and Ukrainian cultural projects that sprang up in Kyiv amidst the violence of the civil war in 1918. The workshop was in large part sponsored by the Dmytro Shtohryn Endowment.

He was a man of incredible commitment, modesty, kindness, open mindedness, and good will. His family, friends, and colleagues from around the world will miss him immensely and will carry on his legacy.

VALERIA SOBOL AND JOSEPH LENKART University of Illinois at Urbana-Champaign 